\author{
Charles M. Rush \\ Texas Agriculture Experiment Station, Amarillo \\ H.-Y. Liu and R. T. Lewellen \\ USDA-ARS, Salinas, CA \\ R. Acosta-Leal \\ Texas Agriculture Experiment Station, Amarillo
}

\title{
The Continuing Saga of Rhizomania of Sugar Beets in the United States
}

Historically, Beet necrotic yellow vein virus (BNYVV), which causes the disease rhizomania of sugar beet, has caused major reductions in root yield and quality wherever it occurred. In the United States, the disease was first identified in California in 1984 (12), but it now occurs in every major sugar beet production region in the country. Fortunately, strong genetic tolerance to BNYVV, conferred by the $R z l$ gene, was identified soon after rhizomania was discovered in the United States, and it has been incorporated into regionally adapted cultivars that allow profitable sugar beet production in areas infested with the pathogen. Plants possessing $R z l$ are susceptible to infection by $P$. betae and BNYVV, but virus titers remain low, and typically, infected plants exhibit normal, asymptomatic growth. However, in the Imperial Valley of California in 2002, plants in a field planted to a rhizomaniatolerant cultivar began to express symptoms of rhizomania (47). Large strips of diseased plants occurred across the field, and it was soon verified that certain isolates of BNYVV from the California Imperial Valley (CIV-BNYVV) had overcome genetic resistance. In other regions of the United States, individual plants, or clusters of plants, in fields planted to rhizomaniatolerant cultivars have also become infected by BNYVV and developed diagnostic symptoms of severe rhizomania. Although patterns of disease development have varied between California fields and those in other production regions in the United States, the breakdown of genetic resistance has caused considerable concern among those involved in sugar beet production. The purpose of this article is to

Corresponding author: Charles M. Rush E-mail: cm-rush@tamu.edu

DOI: 10.1094/PD-90-0004

This article is in the public domain and not copyrightable. It may be freely reprinted with customary crediting of the source. The American Phytopathological Society, 2006. provide an update on rhizomania and the activities that are currently underway to manage this continuing threat to the U.S. sugar beet industry. A review on the detection and distribution of rhizomania and soilborne viruses associated with sugar beet production in the United States (61), and a second more in-depth review on BNYVV and its vector, Polymyxa betae (Keskin) (60), have been published.

\section{Sugar Beet Statistics}

Sugar beets (Beta vulgaris L.) are produced on approximately 8.1 million hectares in 41 countries around the world. Currently, sugar beets account for $25 \%$ of the world supply of raw sugar, but the majority of production comes from sugar cane. However, in the United States, sugar beets have outpaced sugar cane in sugar production, during 19 of the last 25 years. Total acreage planted to sugar beets in the United States has declined during the last 5 years, but root yield and sugar production have increased. From 1990 to 1999 , the average yield from 587,000 ha was 46.5 t/ha and $14.5 \%$ sucrose, while from 2000 to 2004 total acreage dropped to 573,000 ha but tonnage and percent sucrose increased to 49.6 t/ha and $15.3 \%$, respectively. This increase in root yield and quality can be attributed primarily to improved cultivars and management practices. In 2005 , sugar beets were projected to be planted on 544,939 ha, average $51.4 \mathrm{t} / \mathrm{ha}$, and yield 4.3 million metric tons of raw sugar, $58 \%$ of total domestic production (United States Department of Agriculture Economic Research Service (USDA-ERS) website, forecast based on processor's projections compiled by the Farm Service Agency).

In the United States, sugar beets currently are produced in four distinct geographic regions, including the Great Lakes (Michigan and Ohio), Upper Midwest (Minnesota and North Dakota), Great Plains (Colorado, Montana, Nebraska, and Wyoming), and Far West (California, Idaho, Oregon, and Washington) (Fig. 1).
Delineation of specific production regions has always been somewhat objective, but the number of regions has changed over the last 10 years due to cessation of production in a number of areas, primarily due to factory closings. Of the four regions, the Upper Midwest is by far the largest in terms of production, with approximately $55 \%$ of the acreage and $49 \%$ of total U.S. production. In 2003, this region, plus a production area in eastern Montana, produced 13.2 million metric tons of beets, averaging $41.9 \mathrm{t} / \mathrm{ha}$, which generated $\$ 1.1$ billion from production and processing activities and $\$ 3.1$ billion in gross business volume. Despite the fact that sugar beets in this region are planted on relatively few acres, compared to other commodities such as corn and soybean, the economic impact on the region is highly significant, and the gross business volume of the sugar beet industry has increased $76 \%$ since 1987 (3).

Although the Upper Midwest holds regional production records, the Imperial Valley of California in the Far West Region holds the world record for sugar production on an individual farm. In 2004, Desert Sky farms out of Brawley set a new world record by producing an average root yield of $157.2 \mathrm{t} / \mathrm{ha}$ with $15.1 \%$ sucrose (23.7 metric tons sucrose/ha) on a 39-ha field. Environmental conditions were exceptionally favorable for sugar beet yield and quality, and the entire Imperial Valley set a new record for root yield with an average of $97 \mathrm{t} / \mathrm{ha}$ and $16.17 \%$ sucrose. Sucrose per hectare averaged $15.7 \mathrm{t} / \mathrm{ha}$, second only to the 2003 crop that averaged $15.93 \mathrm{t} / \mathrm{ha}$ (6). These production records are all the more remarkable when one considers the fact that the sugar beet industry in the Imperial Valley was nearly destroyed by rhizomania in the late 1980s. They also provide tangible evidence to the effectiveness of the $R z 1$ gene and the rhizomania-tolerant cultivars that are producing outstanding crops in the presence of BNYVV. This region, which was nearly taken out of production due to rhizomania and then rebounded to produce 
world record yields, is now the first to be threatened by an apparently new strain of BNYVV capable of overcoming the Rzl gene. This new strain is especially troubling because, at present, genetic resistance to BNYVV in most commercially available cultivars is based on the $R z l$ gene.

\section{A Brief Overview of BNYVV and Rhizomania}

BNYVV is the type member of the genus Benyvirus, which also includes Beet soilborne mosaic virus (BSBMV) and the tentative member Burdock mottle virus (BdMV) $(60,68)$. Members of the genus are vectored by the plasmodiophorid $P$. betae and are characterized by a plus sense, polyadenylated, quadripartite genome, although some isolates of BNYVV possess a fifth RNA species $(30,35,56$, 57,68). RNA 1 and 2 are essential for infection and always present in infected host tissue (29). RNA 3 is associated with symptom development, but maintenance of BNYVV by repeated mechanical transfer to local lesion hosts is likely to cause internal deletions, which can impact symptom development, or complete loss of the two smaller RNA species $(25,26,29)$. BNYVV has a worldwide distribution and is widespread in every major sugar beet production region in the United States $(57,60,61)$.

BNYVV causes rhizomania of sugar beet. Sugar beets are susceptible to infec- tion throughout their lifetime, but the disease is most devastating when beets are infected early in the growing season. When this occurs, root yield and percent sucrose both are likely to be significantly reduced. When plants are infected later in the growing season, sucrose content will be reduced but root yield will likely be unaffected. The necrotic yellow vein symptom after which BNYVV is named is rarely seen in the field, but plants exhibiting bright fluorescent yellow foliage are common (Figs. 2 and 3). Excess nitrogen can mask foliar symptoms, and some infected plants never exhibit foliar symptoms. The diagnostic root symptoms of rhizomania, which are most likely to develop when plants are infected early in the growing season, include stunting, constriction, and extensive root proliferation (Fig. 4). Late-season infections often cause no observable root symptoms but can significantly reduce sucrose content. Infection of sugar beet roots by aviruliferous $P$. betae causes minimal damage. Incidence and severity of rhizomania can be reduced with cultural practices and sanitation, but the most effective means of disease management has been through the use of resistant cultivars $(4,20,21,75)$.

Life cycle of $\boldsymbol{P}$. betae. BNYVV survives inside the thick-walled resting spores of its vector P. betae (Fig. 5), but there is no indication that the virus multiplies inside the spore $(1,9)$. Clusters of these resting spores, termed sporosori, are capable of surviving free in the soil for years and are practically impossible to eliminate once introduced into a field. For this reason, once a field is thoroughly infested with viruliferous $P$. betae, lengthening crop rotation or introducing a nonhost crop into the rotation is ineffective in reducing disease incidence. In the presence of a susceptible host and near saturated soil moisture conditions, resting spores germinate to release viruliferous primary zoospores. Zoospores of $P$. betae carry the virus particles internally instead of attached to the external zoospore cell wall (9). Upon contact with a susceptible host cell, the primary zoospore encysts, and contents of the encysted zoospore, including the virus particles, are injected into the host cell. Once inside the cell, contents of the zoospore develop into a multinucleate plasmodium. The plasmodium then develops into either a sporangial plasmodium, which releases secondary zoospores that repeat the infection cycle, or a sporogenic plasmodium, which converts to a sporosorus (5). Secondary zoospores of $P$. betae may be released into the soil environment or encyst almost immediately and penetrate adjacent cells, resulting in roots in which almost every cortical cell has become infected (60). Systemic movement of BNYVV from infected cells usually is limited to a few cells surrounding the initial zoosporic infection site (27). This is possibly significant with regard to development and increase of new strains, be-

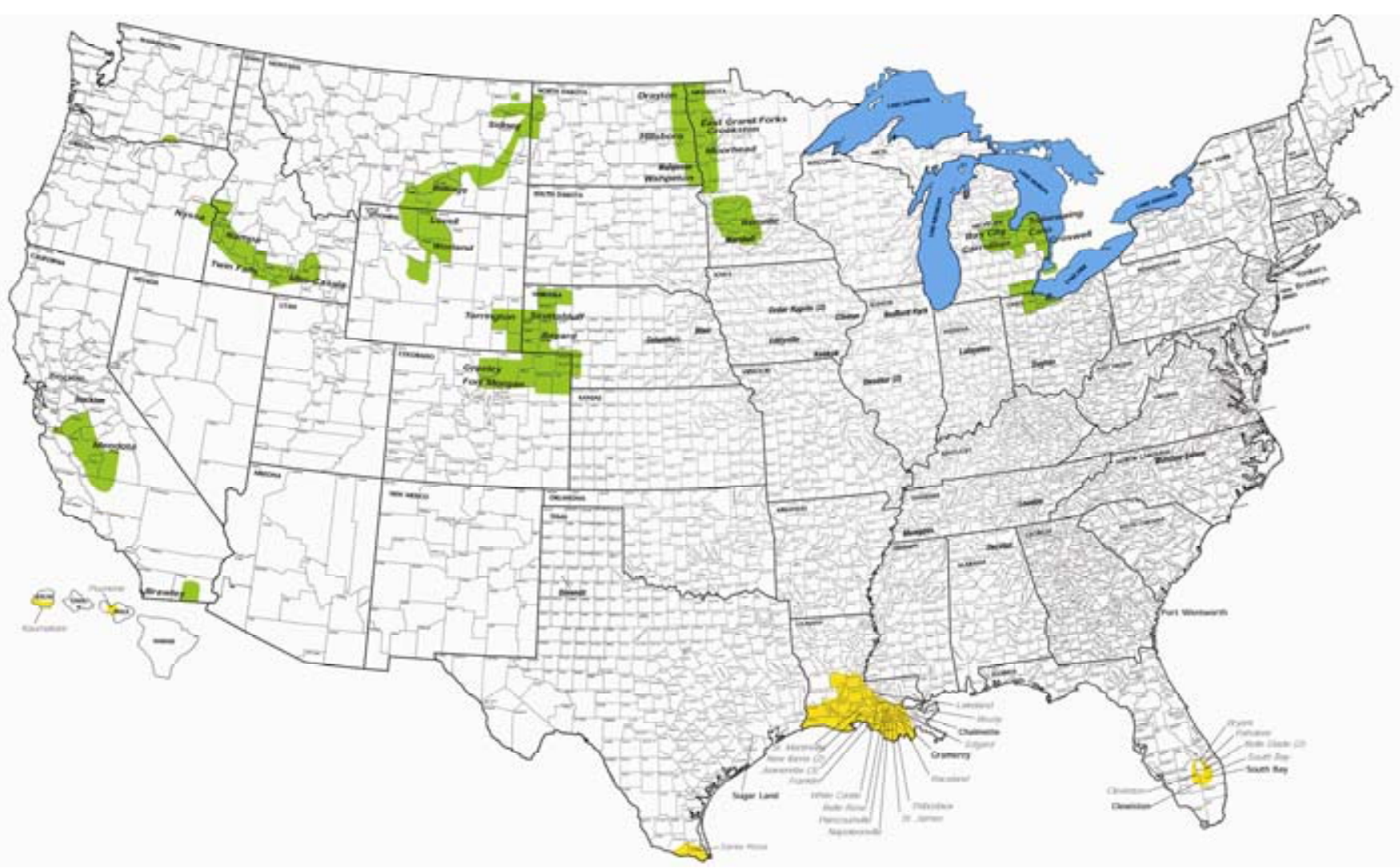

Fig. 1. Major sugar beet and sugar cane production regions in the United States. Green areas represent sugar beet production and yellow designates sugar cane production. (Courtesy Don Lilleboe. Copyright Lilleboe Communications Ltd.) 

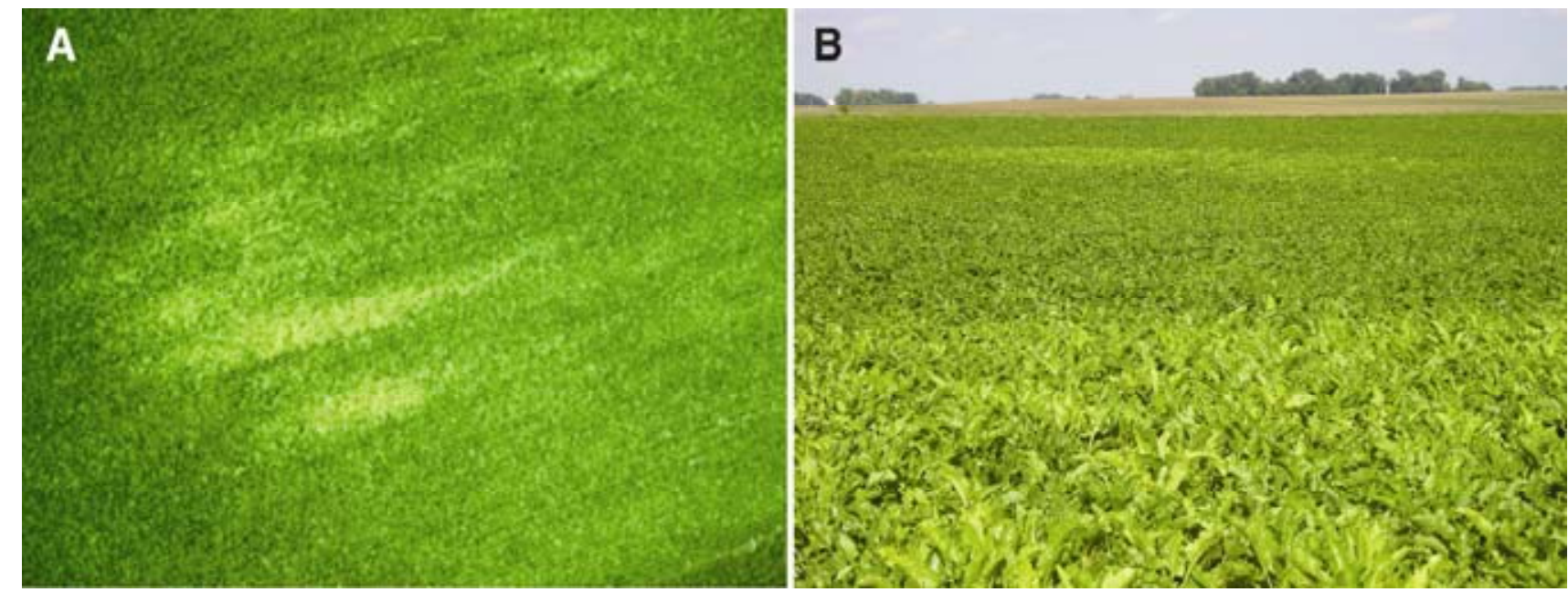

Fig. 2. Foliar chlorosis typically associated with rhizomania. Before Beet necrotic yellow vein virus (BNYVV) is spread throughout a field, discrete patches of infected plants with fluorescent yellow foliage are easily spotted from the air (A) or at ground level (B). These patches often are the first indication that a field is infested by BNYVV.

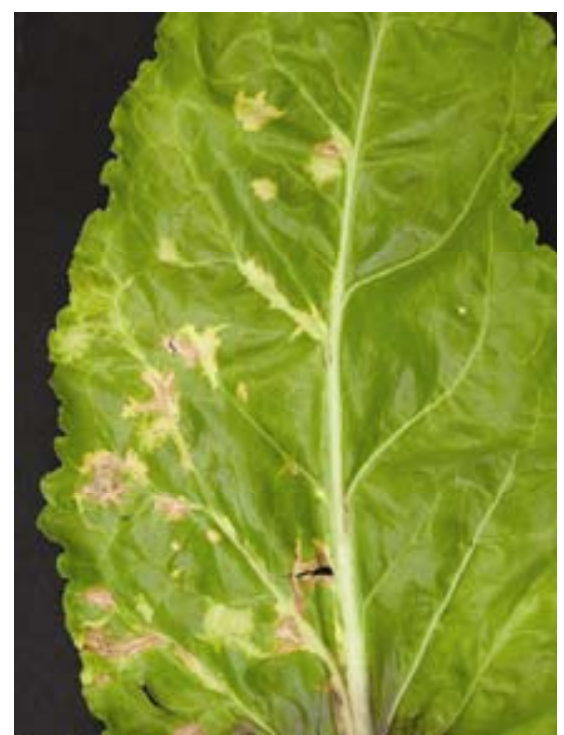

Fig. 3. Necrotic yellow vein symptoms of Beet necrotic yellow vein virus are rarely seen in the field.

cause even if a new virulent strain infected a plant, restricted systemic movement from the initial infection site would limit the number of viruliferous zoospores or sporosori of $P$. betae that carried the new strain. Although a low number of individual plants might express symptoms, significant yield loss from the new virulent strain likely would not be observed until populations of viruliferous $P$. betae carrying the new strain became dominant in the field.

Taxonomy and variability in BNYVV. In 1987, the International Committee on the Taxonomy of Viruses (ICTV) defined members in the genus Furovirus as fungaltransmitted, rod-shaped viruses with bipartite single-stranded RNA genomes. Members shared numerous physical and biological properties but exhibited extreme variability in a number of other traits, including number of RNA species, polyadenylation, serological properties, nucleotide sequence, and genomic organization $(13,23,28,67,71,73)$. Based on these differences, the genus Furovirus was revised into four separate genera, Furovirus, Pomovirus, Pecluvirus, and Benyvirus $(49,67,68,71,73)$.

Viruses that are vectored by $P$. betae and infect sugar beet include Beet soilborne virus and Beet virus $Q$, both members of the genus Pomovirus, and BNYVV and BSBMV, which are members of the genus Benyvirus $(60,68,73)$. Beet soilborne virus, Beet virus $Q$, and BSBMV all exhibit an exceptionally high degree of genomic variability, and multiple isolates of these from the same field can display significant differences in nucleotide sequence $(7,28,72)$. Conversely, isolates of BNYVV from around the world have been found to exhibit a high degree of nucleotide sequence homology. However, variability has been identified, and three major strains of BNYVV, designated as A, B, and $\mathrm{P}$ types, have been described (30-33).

Differentiation of strains of BNYVV initially was based on single-strand conformation polymorphism (SSCP) analysis of reverse transcription-polymerase chain reaction (RT-PCR) products from the coat protein $(\mathrm{CP})$ region $(32,33)$. The A type is widespread throughout Europe, the United States, Japan, and China, while the B type is primarily found in Germany and France. Nucleotide sequences among isolates within A or B types are highly conserved (typically $\geq 99 \%$ sequence identity), but between $\mathrm{A}$ and $\mathrm{B}$ types, differences of 3 to $6 \%$ are typical $(31,51)$. No differences in pathogenicity between $\mathrm{A}$ and $\mathrm{B}$ types have been reported, and they cannot be distinguished serologically.

The P stain of BNYVV is also serologically indistinguishable from A and B types $(31,33)$. However, it possesses biological and genomic properties that make it significantly different from the other strains. $P$ type isolates of BNYVV have a relatively limited geographic distribution. Originally they were found only in France, but now they have been identified in England and Kazakhstan (17,31). Recent studies have revealed that $\mathrm{P}$ types are closely related to the A type (51), but $\mathrm{P}$ types are highly aggressive and able to cause significant damage in some rhizomania-tolerant cultivars. P types also possess five RNA species and are the only BNYVV isolates in Europe found to possess RNA 5. BNYVV isolates with RNA 5 have not been found in the United States and are rare in Europe but common in Japan. Numerous studies and reviews concerning genomic variability and strain designations in BNYVV have been published $(13,24,30$ $32,34,47,52,60,62,70)$.

\section{Genetic Resistance Against BNYVV}

After rhizomania was originally found in the United States (12), the USDA-ARS breeding program at Salinas, CA, did an extensive search to identify genetic variability for reaction to BNYVV, to find sources of resistance, and to develop resistant and enhanced-germ plasm and breeding lines (4). The so-called "Holly" resistance or "Holly" gene was found in 1983 by A. W. Erichsen at Tracy, CA, in the Holly Sugar Company breeding program and was shown to be inherited as a single dominant major gene (44). This gene, which conferred strong resistance against BNYVV, was named $R z 1 \quad(36,63)$. Other than $R z 1$ and the resistance in the cultivar Rizor developed by SES in Italy $(4,8,10)$, no other major gene resistance was identified within sugar beet $(4,66)$.

Although $R z l$ was the primary source for disease resistance, it was apparent in field trials that different degrees of susceptibility or tolerance occurred within sugar beet breeding lines. Lines C39 and C47 were more tolerant than most other breeding material as measured by symptoms and 

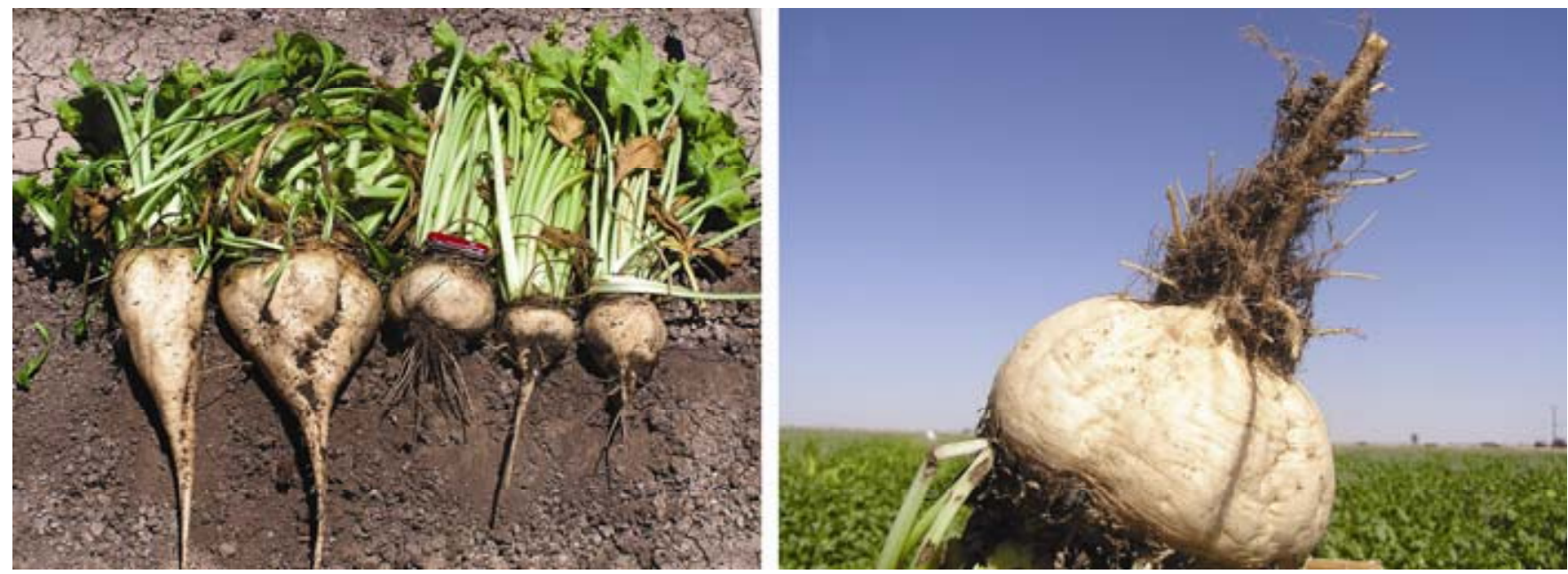

Fig. 4. Diagnostic root symptoms of rhizomania. Early infection of sugar beets results in root stunting, constriction, and proliferation of small secondary roots.

sugar yield $(38,42,44)$. Recurrent phenotypic selection, based on visual disease ratings and yield of individual plants grown under severe disease conditions in the field, was used to make improvements. After five cycles of selection, breeding lines $\mathrm{C} 39 \mathrm{R}$ and $\mathrm{C} 47 \mathrm{R}$ were developed $(38,42)$. Based upon disease symptoms and yield selection under severe rhizomania conditions, the level of resistance in C39R and $C 47 \mathrm{R}$ was equal to that conditioned by $R z 1$ (42). This resistance was quantitative or additive and was transmitted to experimental hybrids to an intermediate (midparent) level compared with the dominant Rzl allele. The C39R type resistance reduced symptom expression (Table 1), but did not reduce BNYVV titer in infected roots (42), and its use in breeding programs has been minimal. The $R z l$ allele was much easier to control and follow in breeding programs and lent itself to rapid deployment in backcrosses and population improvement programs using either symptom expression, enzyme-linked immunosorbent assay (ELISA) values for BNYVV, or marker assisted selection $(14,54,65)$. Quickly, $R z 1$ became the favored resistance against rhizomania worldwide, although it was observed that the partial resistance of $R z l$ did not perform equally in all backgrounds or hybrid cultivars. The Rzl cultivars with the best expression of resistance may have resistance supported from quantitative or minor gene additive resistance as found in $\mathrm{C} 39 \mathrm{R}$ and C47R. Rzl acts in a partially dominant manner, and the $R z, 1$ allelic dosage in diploid versus triploid hybrid cultivars typically results in reduced disease incidence and severity, especially in the presence of high inoculum densities of the pathogen (75).

With the knowledge that single dominant resistance genes are frequently vulnerable to loss due to selection pressure they exert on the pathogen population, the search for additional resistance genes was not abandoned. With the lack of further

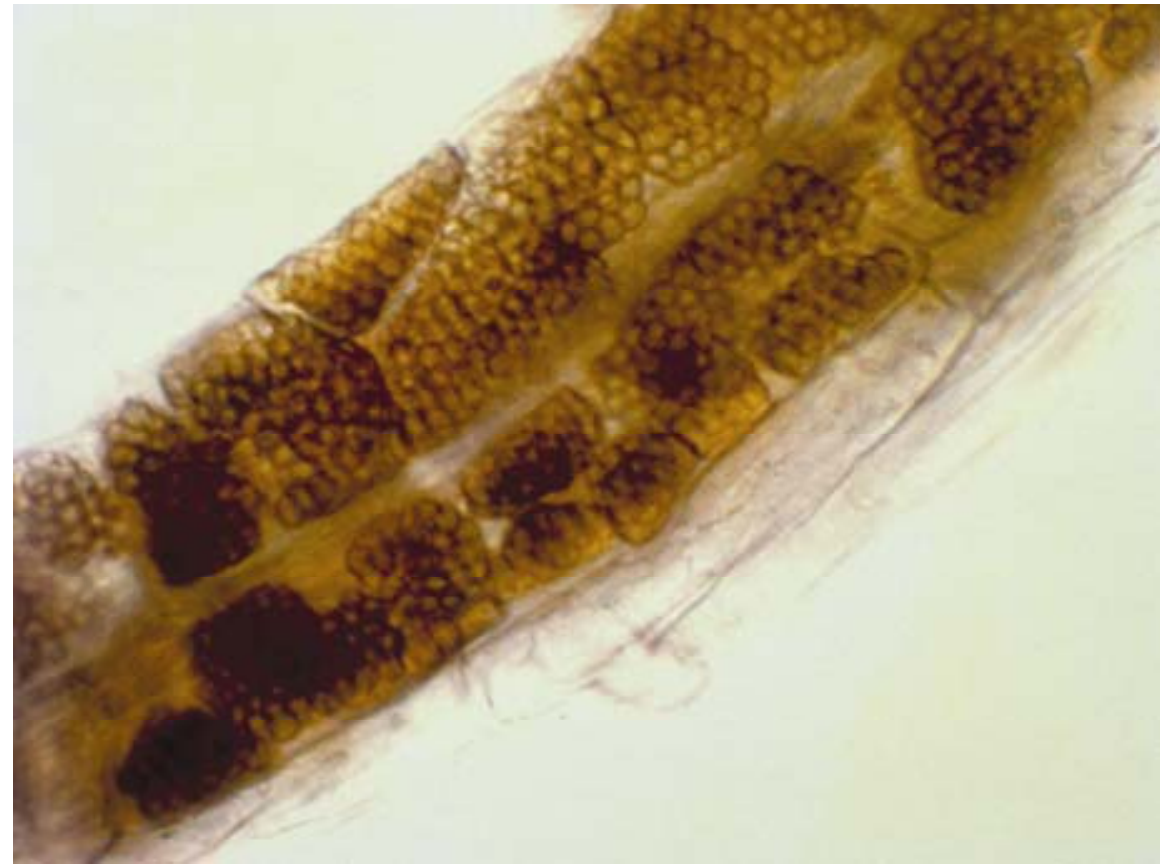

Fig. 5. Sporosori of Polymyxa betae. Rootlets infected by Beet necrotic yellow vein virus (BNYVV) become necrotic and die, and eventually viruliferous sporosori are released into the soil. BNYVV can remain viable in sporosori for years. (Photo courtesy Mike Adams, Rothamsted)

success within sugar beet itself, the search for resistance was quickly expanded to other B. vulgaris germ plasm resources and particularly to $B$. vulgaris subsp. maritima, the ancestral form of all cultivated beet. Two general breeding approaches were used. One was to target specific individual accessions or plant introductions (PI), and the other was to search within pooled or composited collections. In the first, when resistance was found within a specific accession, that resistance was backcrossed into sugar beet breeding lines. Resistance was identified in a number of accessions in field $(37,39)$ and greenhouses studies, using ELISA as an initial screening method (74). For example, the resistance found in $B$. vulgaris subsp. maritima accession WB42 was crossed into sugar beet breeding line C37 (46) and was released as C48 (45) and C79-3 (39) (Table 1). Subsequently, resistance from WB42 was shown to be at a different locus than $R z 1$, conditioned a higher level of resistance in growth chamber tests, and was named Rz2 $(63,64)$. Continuing research has shown that most of the identified sources of resistance in accessions of B. vulgaris subsp. maritima are Rzl or $R z 2$, but every case has not been determined (4). Recently, a third resistance gene has been reported (16). This gene has been named $R z 3$ and is linked to $R z 1$ and $R z 2$ on chromosome III. Rz3 may show incomplete penetrance with the heterozygotes varying widely in expression of resistance. 
Table 1. Screening for resistance to CIV-BNYVVa in greenhouse and field tests, Salinas, CA, 2004

\begin{tabular}{|c|c|c|c|c|c|c|c|c|}
\hline \multirow[b]{2}{*}{ Cultivar or line } & \multirow{2}{*}{$\begin{array}{c}\text { Description } \\
\text { (lit cited) }\end{array}$} & \multirow[b]{2}{*}{ Genes $^{d}$} & \multirow[b]{2}{*}{$\mathbf{H}$} & \multicolumn{2}{|c|}{ Greenhouse ELISA value $^{b}$} & \multicolumn{3}{|c|}{ Hartnell field ${ }^{c}$} \\
\hline & & & & BNYVV & CIV-BNYVV & DI & $\% \mathbf{R}$ & Sugar yld $\left(\mathrm{kg} \mathrm{ha}^{-1}\right)$ \\
\hline \multicolumn{9}{|l|}{ Hybrids } \\
\hline US H11 & Susc. check & $\ldots$ & 1.0 & 4.6 & 12.4 & 4.7 & 10 & 4,700 \\
\hline Beta6600 & Susc. check & $\ldots$ & 1.0 & 6.5 & 13.8 & & & \\
\hline Roberta & Susc. check & $\ldots$ & & & & 5.0 & 4 & 6,500 \\
\hline Phoenix & Commercial & $R z 1$ & & & & 3.7 & 25 & 7,700 \\
\hline Rizor & Commercial & $?$ & & & & 4.3 & 11 & 7,300 \\
\hline Beta4430R & Commercial & $R z 1$ & 1.0 & 1.1 & 12.8 & 2.6 & 48 & 9,600 \\
\hline Angelina & Commercial & $R z 1, R z 2$ & 1.0 & 1.3 & 4.6 & 2.3 & 49 & 11,400 \\
\hline \multicolumn{9}{|l|}{ Breeding lines } \\
\hline 03-SP7622-0 & Susc. check & & & & & 5.1 & 3 & 3,300 \\
\hline 01-EL0204 & $(50)$ & $R z 1$ & & & & 2.5 & 42 & 7,900 \\
\hline C69/2 & (41) & $R z 1$ & & & & 3.4 & 20 & 9,600 \\
\hline C39R & (38) & Quant. & & & & 2.6 & 33 & 11,200 \\
\hline C47R & $(38)$ & Quant. & & & & 2.9 & 34 & 10,700 \\
\hline 02 -US $22 / 3$ & Susc. check & $\ldots$ & & & & 4.8 & 3 & 5,100 \\
\hline C37 & (46), susc. check & $\ldots$ & & & & 3.8 & 9 & 5,400 \\
\hline C79-2 & (39), C37×WB41 & $R z 3$ & & & & 3.4 & 18 & 6,300 \\
\hline C79-3 & (39), C37×WB42 & $R z 2$ & 1.0 & 0.9 & 8.3 & 3.4 & 13 & 6,500 \\
\hline C79-8 & (39), C37×Bvm & $B v m$ & & & & 3.5 & 21 & 6,200 \\
\hline C79-C & $\mathrm{C} 37 \times B v m$ & $R z 2, B v m$ & & & & 2.9 & 33 & 8,400 \\
\hline \multicolumn{9}{|c|}{ Sugar beet $\times B$. vulgaris subsp. maritima } \\
\hline $\mathrm{C} 26$ & $(40), C 37 \times B v m$ & $B v m$ & & & & 3.2 & 32 & 7,300 \\
\hline $\mathrm{C} 27$ & (40), C69/2×Bvm & $R z 1, B v m$ & & & & 2.9 & 37 & 8,000 \\
\hline R21 & $\mathrm{C} 26 \times \mathrm{C} 27$ & $R z 1, B v m$ & 1.0 & 1.0 & 11.9 & 3.3 & 23 & 7,600 \\
\hline $\mathrm{C} 67 / 2$ & $(41), C 78 \times C 51$ & $R z 1, B v m$ & 1.0 & 1.0 & 9.0 & 3.0 & 31 & 9,000 \\
\hline \multicolumn{9}{|c|}{ B. vulgaris subsp. maritima } \\
\hline R423 & (40), Bvm composite & $B v m$ & & & & 3.2 & 30 & $\ldots$ \\
\hline R423B & (40), Bvm composite & $B v m$ & & & & 2.8 & 36 & $\ldots$ \\
\hline R720 & (40), Bvm composite & $B v m$ & & & & 3.3 & 32 & $\ldots$ \\
\hline $\operatorname{LSD}(0.05)$ & & & 2.8 & 2.8 & 2.8 & 1.1 & 20 & 1,900 \\
\hline
\end{tabular}

a CIV-BNYVV = Beet necrotic yellow vein virus isolates from the Imperial Valley of California associated with overcoming genetic resistance conferred by the $R z l$ gene.

${ }^{\mathrm{b}}$ Roots from baited seedling plants grown in flats where $\mathrm{H}=$ healthy soil (sterilized), BNYVV = soil from Salinas, CA, rhizomania trial field, and CIV-BNYVV = soil from Rockwood 158, Imperial Valley. ELISA values $=$ ratio of the absorbance at $405 \mathrm{~nm}$ reading for sample over corresponding healthy absorbance value. Ratio of $\geq 3 \times$ the healthy mean are considered infected.

c Sown as 96 entry $\times 4$ reps, RCB on 5 May 2004; harvested 18 November 2004 in Hartnell field, Salinas, CA that had been inoculated with CIVBNYVV from Rockwood 158, Imperial Valley, CA. Roots were scored for reaction to BNYVV on a scale of 0 to 9 where 0 is nondiseased and 9 is dead. $\mathrm{DI}=$ disease index, the average score per root. $\% \mathrm{R}=\%$ resistant plants in each plot where only beets with a rating of 0 or 1 were considered resistant.

${ }^{\mathrm{d}}$ Quant. = quantitative resistance without known major gene resistance. Bvm = resistance from Beta vulgaris subsp. maritima but nature of resistance factors is unknown.

$R z 3$ was mapped in crosses of sugar beet to B. vulgaris subsp. maritima WB41 accessed from Denmark at the same time as WB42. Earlier, WB41 was shown to have resistance to rhizomania (74) and had been introgressed into sugar beet lines C48 (45) and C79-2 (39) (Table 1). Plants with combined $R z 1$ and $R z 3$ in a heterozygous condition had lower BNYVV titers than $R z 1$ alone (16).

In the second approach, collections of $B$. vulgaris subsp. maritima, such as the collections of Doney et al. (11), were individually screened for resistance to rhizomania, but selected plants were pooled and increased in mass. For example, populations that lead to C26, C27, and C51 (40), R21 and C67/2 (41), and R23, R23B, and R20 (40) were produced (Table 1). For these populations, no attempt was made to determine if resistance was due to $R z 1$, $R z 2$, or other factors. However, by 2002 when the CIV-BNYVV strain appeared, an extensive germ plasm base with resistance to rhizomania had already been developed, and these very broadly based germ plasm populations that had been improved for resistance to rhizomania and sugar beet traits were among the first lines evaluated for reaction to CIV-BNYVV.

\section{Breakdown of Rhizomania Resistance in the Imperial Valley}

During the growing season of 20022003 in the Imperial Valley of California, a number of sugar beet fields planted to BNYVV-tolerant cultivars were observed to have severe symptoms of rhizomania. This suggested that the resistance conditioned by the $R z l$ gene had been compromised. Infested sugar beet fields showed infected plants in adjacent rows that appeared as irregularly spaced chlorotic strips that ran the length of the field (Fig. 6). Infected plants exhibited typical rhizomania symptoms of fluorescent yellow foliage and stunted taproots with a proliferation of small secondary lateral roots.

To verify that resistance-breaking BNYVV isolates existed in the Imperial
Valley, a series of experiments were conducted using two infested field soils, sugar beet cultivars with varying levels of resistance to BNYVV, and ELISA. Commercially available rhizomania-tolerant varieties grown in BNYVV-infested soil from Salinas, CA, tested negative by ELISA. When the same cultivars were grown in soil from the Imperial Valley fields infested with CIV-BNYVV where disease had developed, the resistant varieties became severely infected and tested positive. However, in these tests, the cultivar Angelina, which has two genes for resistance (Rz1rz1, Rz2rz2), had a considerably lower ELISA value than those of the susceptible check, which suggested that the additional resistance gene $R z 2$ was able to confer partial resistance against CIV-BNYVV (Fig. 7) (47). Although these tests provided strong evidence that CIV-BNYVV isolates were actually a new strain or pathotype, additional tests were required to address the possibility that disease was the result of exceptionally high inoculum density in 

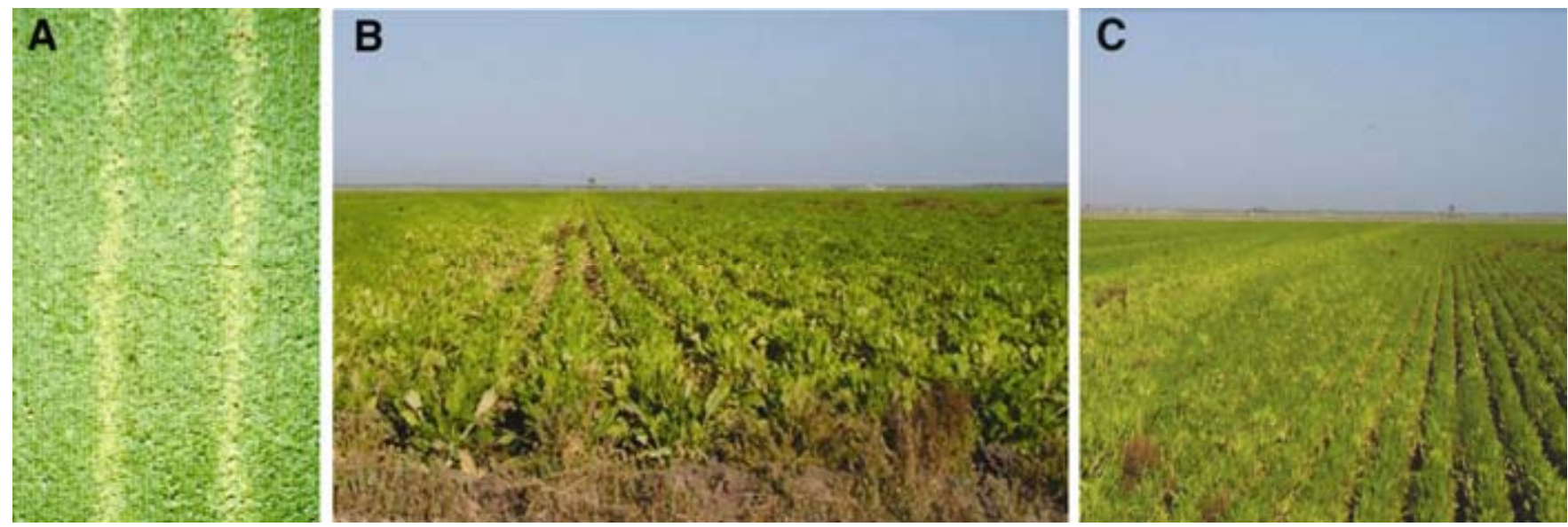

Fig. 6. Aerial and ground views of rhizomania in fields planted to rhizomania-resistant cultivars in the Imperial Valley of California. A, Infected symptomatic plants in adjacent rows formed strips that repeated at irregular intervals and ran the length of the field (Photo courtesy David Melin). B, In the Imperial Valley, root rot and plant death are often associated with severe rhizomania, especially as temperatures increase during early summer. C, Symptomatic plants branching off at an angle from the main strips result from tillage spreading the CIV strain of Beet necrotic yellow vein virus into new areas.

the Imperial Valley soils, or that the CIV isolates were just unusually aggressive.

Under high levels of inoculum density and environmental conditions optimum for rhizomania, disease resistance may break down, especially in partially resistant cultivars (2). Soil dilution experiments were initiated with resistant and susceptible cultivars, but the results provided no evidence that inoculum level affected disease severity on rhizomania-tolerant cultivars in CIV-BNYVV-infested soil (47). Likewise, plants of a susceptible and a rhizomaniatolerant cultivar were inoculated with wildtype BNYVV or a CIV isolate, and virus titer was measured using real time PCR. With the rhizomania-susceptible cultivar, there was no significant difference in virus titer between plants inoculated with the wild-type or CIV isolate of BNYVV, but in the rhizomania-tolerant line, the virus titer in plants inoculated with the CIV strain was significantly higher than in plants inoculated with the wild-type isolate (C. Rush, unpublished data). If disease development in rhizomania-tolerant cultivars was merely a matter of isolate aggressiveness, then the CIV isolate also would have been more aggressive on the rhizomaniasusceptible cultivar, but there was no difference in wild-type and CIV-BNYVV virus titer on those plants.

Isolation of resistance-breaking BNYVV isolates from the Imperial Valley. Root samples of symptomatic plants from fields planted to rhizomania-tolerant cultivars in the Imperial Valley were used as inoculum in mechanical inoculations of Chenopodium quinoa Willd., a local lesion host of BNYVV. Single local lesion isolates of CIV-BNYVV were collected and subinoculated to a selection of different host plants. Eight pathotypes of BNYVV from the Imperial Valley were identified based on reactions of each host, and all eight CIV-BNYVV isolates were capable of infecting the three BNYVV-resistant

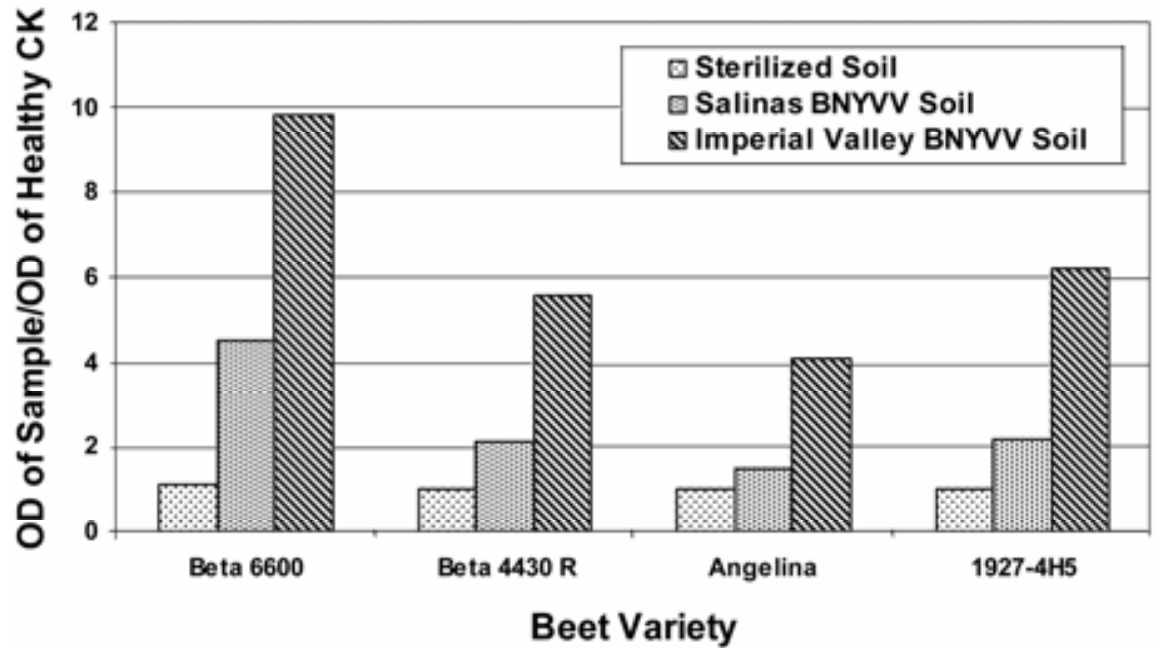

Fig. 7. Enzyme-linked immunosorbent assay (ELISA) $\boldsymbol{A}_{405 \mathrm{~nm}}$ values ( $\boldsymbol{A}_{405 \mathrm{~nm}}$ of sample/ $A_{405 \mathrm{~nm}}$ of healthy check) of sugar beet cultivars grown in Imperial Valley soil compared with Salinas Beet necrotic yellow vein virus (BNYVV)-infested soil and sterilized check. ELISA values 3 times greater than the healthy check were considered positive. Sugar beet cultivars used were resistant to BNYVV: Beta 4430 R (Rz1rz1), Angelina (Rz1rz1 + Rz2rz2), experimental hybrid 1927-4H5 (Rz1rz1 + wild beet resistance), and a triploid rhizomania-susceptible Beta 6600 (rz1rz1rz1). Rz1rz1 and Rz2rz2 are dominant alleles at two separate loci.

sugar beet cultivars tested (47). CIVBNYVV and Salinas BNYVV (a wildtype isolate) both showed systemic infection in Beta macrocarpa. However, after mechanical inoculation to sugar beet, Salinas BNYVV produced chlorotic local lesions while CIV-BNYVV isolates were either nonpathogenic or produced systemic infections. On Chenopodium capitatum, Salinas BNYVV showed chlorotic local lesions and CIV-BNYVV isolates had a variety of different reactions, including chlorotic and necrotic local lesions, and some isolates showed systemic infection. Except in B. macrocarpa, it has been rare for BNYVV to produce systemic infection from mechanical inoculation in Beta species (43). Most isolates of CIV-BNYVV that are mechanically in- oculated onto sugar beet produce systemic infection, suggesting a fundamental difference between CIV and wild-type isolates of BNYVV. It is unknown if this difference is related or coincidental to the increased pathogenicity of CIV-BNYVV against $R z l$.

\section{Breakdown of Rhizomania Resistance in Minnesota}

In 2002, agriculturalists working with the Southern Minnesota Sugar Beet Cooperative began to notice individual plants with typical symptoms of rhizomania in fields planted to rhizomania-tolerant cultivars. Subsequent testing verified that the plants were infected by BNYVV. These individual symptomatic plants, which possessed fluorescent yellow foliage typical of 
Table 2. Comparisons between asymptomatic sugar beets and blinkers ${ }^{\mathrm{a}}$ for several variables

\begin{tabular}{lccccc}
\hline Plant type & Disease rating & Positive for $\boldsymbol{R z} \mathbf{1} \mathbf{g e n e}^{\mathbf{c}} \mathbf{( \% )}$ & Reflectance at $\mathbf{5 5 5} \mathbf{~ n m}$ & BNYVV positive (\%) & Sucrose (\%) \\
\hline Blinkers & 2.95 & 42 & 26.58 & 88 & 13.98 \\
Healthy & $1.14^{* * \mathrm{~d}}$ & $80^{* *}$ & $19.04^{* *}$ & $44^{*}$ & $15.67^{* *}$ \\
\hline
\end{tabular}

a "Blinker" is the term used to describe an individual sugar beet infected by Beet necrotic yellow vein virus (BNYVV), which exhibits the fluorescent yellow foliage typically associated with rhizomania surrounded by asymptomatic beets with dark green foliage.

b Severity of rhizomania was based on a 0 to 4 scale, where $0=$ healthy disease-free roots and $4=$ severe stunting, root constriction, and massive root proliferation.

${ }^{c}$ Presence of the $R z 1$ gene was determined for the various cultivars by seed company personnel using proprietary technology. Plant samples were coded until results were submitted to ensure unbiased results.

d Asterisks indicate a significant difference, $* P=0.05$ and $* * P=0.01$, between blinkers and healthy plants.

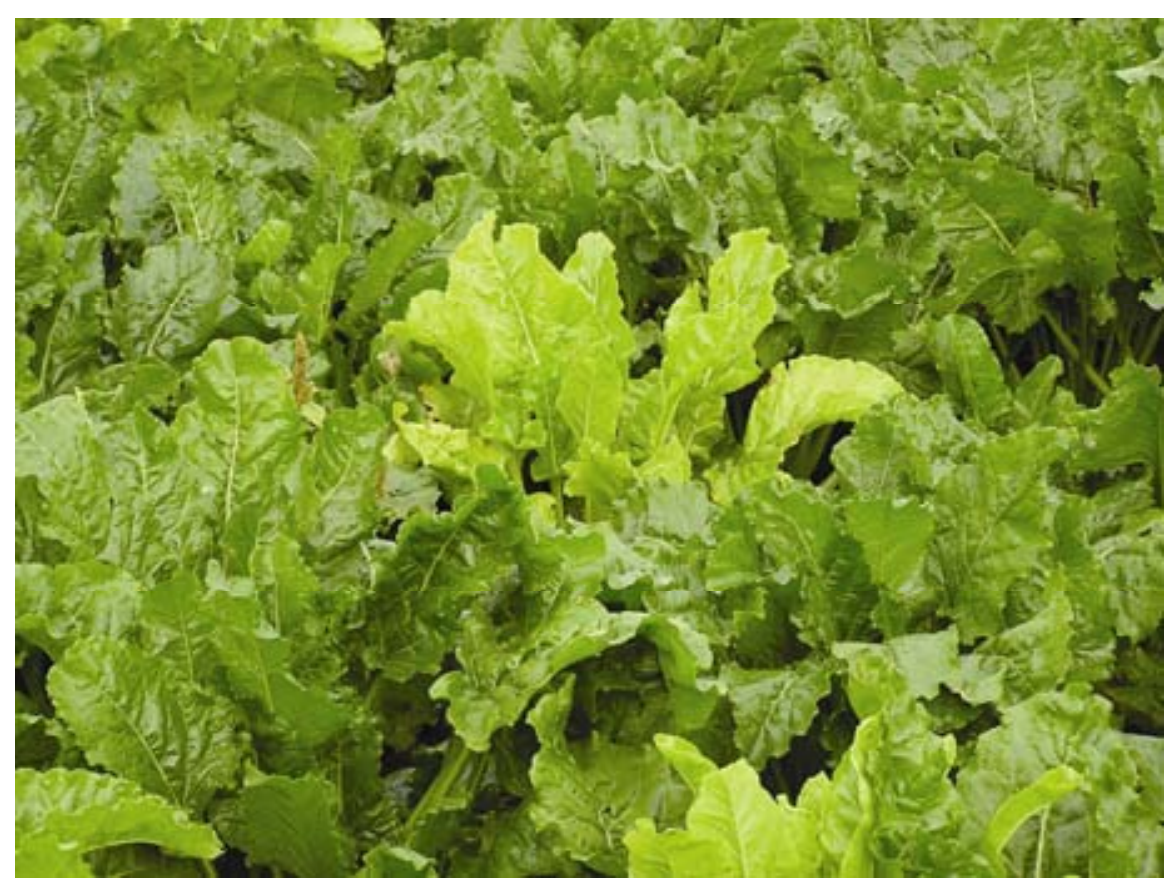

Fig. 8. "Blinker" is the common term used to describe an individual symptomatic plant exhibiting fluorescent yellow foliage in a field of asymptomatic rhizomania-resistant plants.

Table 3. Comparisons between blinkers ${ }^{\mathrm{a}}$ with and without $R z 1$ gene

\begin{tabular}{lcccc}
\hline Blinker genotype $^{\mathbf{b}}$ & $\begin{array}{c}\text { Incidence } \\
(\boldsymbol{\%})\end{array}$ & $\begin{array}{c}\text { Disease } \\
\text { rating }^{\mathbf{c}}\end{array}$ & $\begin{array}{c}\text { BNYVV } \\
\text { positive (\%) }\end{array}$ & $\begin{array}{c}\text { Reflectance } \\
\text { at 555 } \mathbf{~ n m}\end{array}$ \\
\hline$R z 1$ Negative & 57 & 2.88 & 95 & 27.28 \\
$R z 1$ Positive & $42 * \mathrm{~d}$ & $2.93 \mathrm{~ns}$ & $80^{*}$ & $27.61 \mathrm{~ns}$ \\
\hline
\end{tabular}

${ }^{a}$ Blinker is the term used to describe an individual sugar beet infected by Beet necrotic yellow vein virus (BNYVV), which exhibits the fluorescent yellow foliage typically associated with rhizomania, surrounded by asymptomatic beets with dark green foliage.

${ }^{b}$ Presence of the $R z 1$ gene was determined for the various cultivars by seed company personnel using proprietary technology. Plant samples were coded until results were submitted to ensure unbiased results.

c Severity of rhizomania was based on a 0 to 4 scale, where $0=$ healthy disease-free roots and $4=$ severe stunting, root constriction, and massive root proliferation.

$\mathrm{d} *$ Indicates a significant difference, $P=0.05$, between plants testing positive or negative for the $R z 1$ gene. $\mathrm{ns}=$ not significant.

rhizomania, in fields of apparently healthy asymptomatic plants with dark green foliage were termed "blinkers" (Fig. 8). In some instances, blinkers were readily attributable to a mix of resistant and susceptible seed at planting, but in other instances there was no obvious explanation. Because of the reports of a breakdown in genetic resistance in the Imperial Valley of California, sugar beet industry personnel in Minnesota became concerned and questioned whether genetic resistance might be breaking in their production region.

In Minnesota fields planted to rhizomania-tolerant cultivars, disease initially was observed on individual plants and not in large strips or spots as in California. Because there are a number of reasons that could explain disease development in individual plants, it was questioned whether the individual symptomatic plants actually possessed the $R z 1$ gene or whether disease development was a result of some other edaphic or biological factor. In preliminary studies, blinkers and apparently healthy asymptomatic beets were collected from three rhizomania strip trials. Each individual beet was rated for rhizomania severity, and roots with fungal disease symptoms were discarded. Leaf chlorosis was quantified, root samples were tested by DASELISA for presence of BNYVV, leaf samples were tested for presence or absence of the $R z 1$ gene, and percent sucrose was determined. Differences between apparently healthy, asymptomatic beets and blinkers were, for the most part, as expected (Table 2). A significantly greater percentage of healthy plants tested positive for the Rzl gene and negative for BNYVV, compared to the blinkers. Blinkers had a significantly higher disease rating and higher reflectance readings at $555 \mathrm{~nm}$ than the apparently healthy beets and also greatly reduced sucrose content. However, when comparing rhizomania root ratings between blinkers with or without the $R z 1$, there was no significant difference (Table $3)$. These data suggested that presence of the $R z 1$ gene was not conferring any resistance to BNYVV and confirmed that $R z I$ had been compromised. However, results from this preliminary study did not prove the existence of a new virulent strain. Other variables, such as edaphic factors, high inoculum density, interactions with other soilborne pathogens, or the combination of minor genes can impact severity of rhizomania $(15,19,21,22,48,55,76)$.

Preliminary genomic analysis of CIVBNYVV and isolates from Minnesota. Previous studies have revealed that BNYVV isolates containing RNA 5 are highly virulent and can incite disease in partially resistant sugar beet cultivars (69). RNA 5 is common in strain A isolates of BNYVV in Japan, and in sugar beet infected with the P strain in France and England (30). However, in 2002 when disease began to appear in fields planted to rhizomania-tolerant cultivars, only strain $\mathrm{A}$ of 
BNYVV, with four RNA species, had been identified in the United States. Therefore, it was important to determine whether CIV-BNYVV isolates possibly represented an introduction of an $\mathrm{A}$ or $\mathrm{P}$ strain of BNYVV that possessed RNA 5 into the Imperial Valley. Soil from symptomatic fields in the Imperial Valley was planted with seed of a rhizomania-tolerant cultivar to bait out CIV-BNYVV. ELISA was used to confirm BNYVV infection of the resulting plants and total RNA was isolated. An RNA gel was run to tentatively determine whether the CIV isolate contained an RNA 5 species, but no RNA 5 was apparent. This result was verified using PCR and primers specific for RNA 5. Additionally, single-strand conformation polymorphism analyses indicated that the banding patterns of CIV-BNYVV isolates were identical to those of BNYVV strain A and were different from strains $\mathrm{B}$ and $\mathrm{P}$ in amplicons from RNA 1 and RNA-2 (47). These results suggest that CIV-BNYVV represents a new virulent strain of BNYVV that evolved, or was selected, from existing populations of BNYVV in the Imperial Valley, and not an aggressive, newly introduced RNA 5 isolate.

Additional studies were conducted to investigate variability among wild-type and resistance-breaking isolates of BNYVV. Total RNA from asymptomatic plants, CIV-BNYVV-infected plants, and blinkers from Minnesota was reversetranscribed to cDNA for PCR analysis and subsequent sequencing. Nucleotide sequences from CIV and blinker isolates were compared with sequences of BNYVV from GenBank and typically demonstrated $\geq 98 \%$ identity with the previously published BNYVV sequences (C. M. Rush, unpublished data). However, because BNYVV RNA 3 had been implicated with symptom expression and disease severity $(25,26)$, additional analysis of P25, the single ORF on RNA 3, was conducted. Amino acid sequence analysis revealed polymorphisms at positions 67 , 68, and 135 that separated CIV-BNYVV from wild-type BNYVV and isolates from blinkers in Minnesota (Table 4). All CIVBNYVV isolates possessed the $\mathrm{V}_{67} \mathrm{~L}_{68} \mathrm{E}_{135}$ motif, while blinker and wild-type isolates of BNYVV were variable. At this point, only a limited number of isolates have been evaluated, and it is unknown whether the VLE motif is actually associated with virulence. However, CIV-BNYVV isolates clearly can be differentiated from wildtype BNYVV and BNYVV isolates obtained from blinkers in Minnesota, and the ability to differentiate these isolates should be of value in diagnostics and epidemiological studies. Although the precise etiology of resistance-breaking is still unknown, it is clear that $R z l$-based resistance is breaking down and sources of resistance to rhizomania other than $R z l$ are needed.

Table 4. Amino acid substitutions in the Beet necrotic yellow vein virus (BNYVV) P25 protein, associated with resistant-breaking isolates and blinkers from California and Minnesota, respectively $^{\mathrm{a}}$

\begin{tabular}{lllcc}
\hline & & \multicolumn{3}{c}{ Amino acid $^{\mathbf{b}}$} \\
\cline { 3 - 5 } Source & Isolate $^{\mathbf{c}}$ & $\mathbf{6 7}$ & $\mathbf{6 8}$ & $\mathbf{1 3 5}$ \\
\hline California & Ch* $^{*}$ & $\mathrm{~V}$ & $\mathrm{~L}$ & $\mathrm{E}$ \\
& Mag* & $\mathrm{V}$ & $\mathrm{L}$ & $\mathrm{E}$ \\
& DWe* & $\mathrm{V}$ & $\mathrm{L}$ & $\mathrm{E}$ \\
& Spr* & $\mathrm{V}$ & $\mathrm{L}$ & $\mathrm{E}$ \\
& Tam* & $\mathrm{V}$ & $\mathrm{L}$ & $\mathrm{E}$ \\
& Salinas 2005 & $\mathrm{~A}$ & $\mathrm{C}$ & $\mathrm{D}$ \\
\multirow{3}{*}{ Minnesota } & $\mathrm{A}$ & $\mathrm{L}$ & $\mathrm{D}$ \\
& Wt CIV2005 & $\mathrm{V}$ & $\mathrm{C}$ & $\mathrm{D}$ \\
& Blinker $83^{*}$ & $\mathrm{~A}$ & $\mathrm{H}$ & $\mathrm{D}$ \\
& Crookston* & $\mathrm{A}$ & $\mathrm{C}$ & $\mathrm{D}$ \\
& Willmar* & $\mathrm{A}$ & $\mathrm{C}$ & $\mathrm{D}$ \\
& Glendon $1^{*}$ & $\mathrm{~A}$ & $\mathrm{C}$ & $\mathrm{D}$ \\
& Climax* & $\mathrm{A}$ & $\mathrm{C}$ & $\mathrm{D}$ \\
\hline
\end{tabular}

a "Blinker" is the term used to describe an individual sugar beet infected by BNYVV, which exhibits the fluorescent yellow foliage typically associated with rhizomania, surrounded by asymptomatic beets with dark green foliage.

b The $\mathrm{V}_{67} \mathrm{~L}_{68} \mathrm{E}_{135}$ signature was consistently found in resistance-breaking California Imperial Valley (CIV)-BNYVV populations during 2005. Asymptomatic plants from the Imperial Valley are infected by genetically heterogeneous virus populations where $\mathrm{A}_{67} \mathrm{~L}_{68} \mathrm{D}_{135}$ is the predominant signature. The $\mathrm{A}_{67} \mathrm{C}_{68} \mathrm{D}_{135}$ signature frequently has been found in many virus populations collected outside of the Imperial Valley, both from symptomatic and asymptomatic plants.

c Isolates followed by an asterisk represent resistance-breaking CIV-BNYVV from California, or BNYVV isolates recovered from blinkers in Minnesota. Salinas 2005 and Wt CIV 2005 represent wild-type, non-resistance-breaking isolates from Salinas, CA, and the Imperial Valley, respectively. Wt15 2000 is a wild-type isolate from Minnesota.

\section{Efforts to Develop New Sources of Resistance}

In 2002 when it appeared that a new strain of BNYVV had developed or had been selected out of the genetic diversity of BNYVV types (47), the inventory of previously developed germ plasm with resistance to rhizomania was one of the most logical places to search for additional resistance factors. Tests were run in the greenhouse and field at Salinas and Brawley, CA. In those tests, the hybrid cultivars Beta 4430R and Angelina were used as resistant checks (Table 1).

The aggressive P-strain in France is known to cause significant damage against cultivars with only $R z 1$ resistance $(8,17,31,58)$. The hybrid cultivar Angelina, developed by KWS SAAT AG in Germany, possesses both $R z 1$ and $R z 2$ for resistance to BNYVV (17) and has superior resistance against the P-strain $(8,17)$. The cultivar Beta 4430R has the genotype Rz1rz1, $r z 2 r z 2$. Fully susceptible cultivars such as USH11, Beta 6600, and Roberta are $r z 1 r z 1, r z 2 r z 2$. Combinations of these cultivars have been used in the Salinas breeding program as checks to measure ELISA values in bait plants from greenhouse soil tests, and for yield and disease scores in infested field tests (Table 1). Based on ELISA values, $R z 1$ protected against wild-type BNYVV, as represented by infested soil from Salinas fields, but not against CIV-BNYVV from Imperial Valley fields Rockwood 156 and 158 where the first case of defeated resistance was observed (47). When Angelina was exposed to soils from the Rockwood fields in greenhouse tests, bait plants tested positive for BNYVV, but the ELISA value was usually intermediate, suggesting a partial or moderate resistance to CIV-BNYVV.

In 2003-2004, a modified extension of the greenhouse baiting test was run to evaluate sugar beet lines for reaction to BNYVV. Either sterilized Salinas soil, nonsterilized BNYVV-infested Salinas soil, or Rockwood 158 (CIV-BNYVV) soil was mixed with sterilized river sand in a $1: 9$ ratio and placed into $30 \times 60 \mathrm{~cm}$ seedling flats. Ten rows of seed were sown into each flat in random order, and each set of line $\times$ soil treatments was replicated three times. At 6 weeks postemergence, roots from all seedlings within each treatment were combined and tested by ELISA for BNYVV. Some of these data are summarized in Table 1. Under sterilized soil conditions, all entries were negative for BNYVV. Under Salinas BNYVV conditions, only the susceptible checks scored positive (3 times higher than healthy check). Under CIV-BNYVV soil (Rockwood 158), no variety tested resistant $(<3$ times the ELISA value of the healthy check), but Angelina and breeding lines with $R z 2$ and/or $R z 1$ and $R z 2$ were intermediate in ELISA values as compared to entries with only $R z 1$ or no resistance allele. In general, these results matched the results from the tests run by Liu et al. (47) and subsequent field tests at Hartnell (de- 
to condition moderate resistance. Neither of these factors appeared to be sufficient to give high levels of resistance and prevent damage and yield loss in the field. Individual plants in some breeding lines tested as highly resistant and the frequency of these differed among entries. Until follow-up tests are run on the apparently highly resistant individuals selected, we cannot establish if they represent disease escapes, various combinations of $R z 1$ and/or $R z 2$ with minor genes, or if new resistance genes or alleles have been identified. One thing is obvious: with the fairly rapid emergence of BNYVV resistance-breaking strains, sugar beet breeders will be challenged to stay ahead of the disease.

\section{Concluding Thoughts}

In 2002, three fields in the Imperial Valley were identified with the resistance breaking CIV-BNYVV isolates, and in 2003 five additional fields were identified. Because alfalfa, a 3- or 4-year crop, is commonly rotated with sugar beets in the Imperial Valley, sugar beets are often grown 2 years in a row. When CIVBNYVV first appeared, it was always in the second year of consecutive sugar beet crops. Furthermore, diseased plants occurred in several adjacent rows that were flanked on either side by healthy plants, and these diseased strips repeated at irregular intervals across the field (Fig. 6). This spatial distribution is highly unusual for a soilborne pathogen and difficult to explain, but it appeared to be associated with cultural practices. In 2004, 26 fields were identified as containing resistancebreaking isolates, and by June of 2005 over 28 fields had been identified. However, symptoms are now appearing in the first year of the sugar beet rotation, and diseased plants are often clustered in irregular patches. The reason for this change is uncertain, but the observation is significant because it suggests that inoculum densities are now high enough in first-year plantings to cause detectable yield loss.

The occurrence of fields with resistancebreaking CIV-BNYVV isolates is rapidly increasing in the Imperial Valley, but it is difficult to measure how extensive the problem is in other sugar beet production regions of the United States. The occurrence of blinkers in Minnesota demonstrates selective breakdown of resistance. The etiology of this breakdown is unknown, but because sugar beets are grown in 3- to 5-year rotations in the Upper Midwest, the development and impact of resistance-breaking strains could be delayed. However, in 2005, large areas of infected, symptomatic plants appeared in fields planted to rhizomania-tolerant cultivars, similar to the diseased spots caused by BNYVV when the pathogen was originally introduced into the state in 1996 (Fig. 9). Some of these fields exhibited over $50 \%$ symptomatic plants, and it was common to

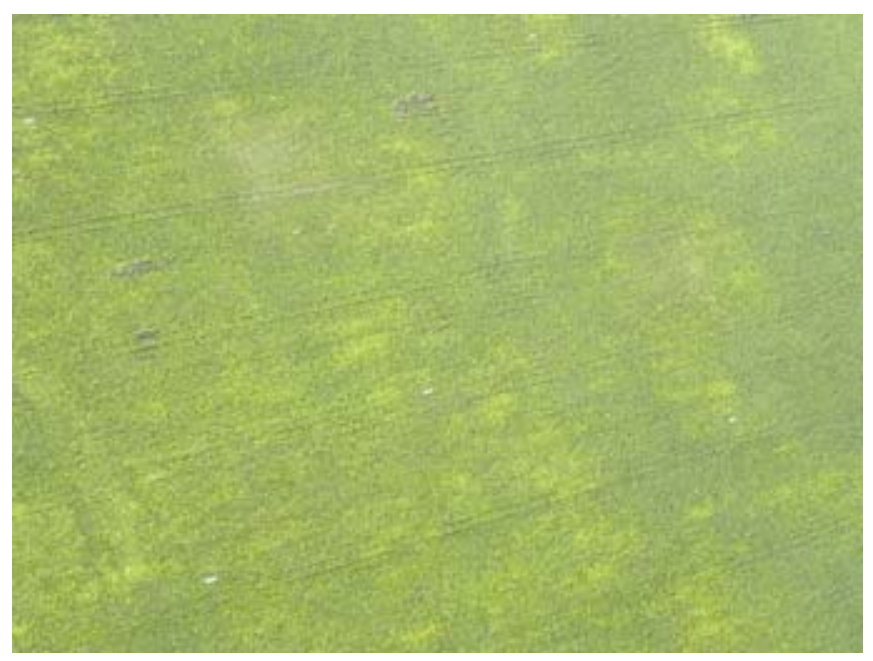

Fig. 9. Aerial view of "rhizomania spots" in a field in Minnesota planted to a rhizomania-tolerant cultivar. The large patches of fluorescent yellow foliage represent clusters of plants infected by Beet necrotic yellow vein virus (BNYVV). The shape and spatial distribution of these is similar to rhizomania spots that were observed when the disease was first detected in Minnesota in 1996.

find fields with over $25 \%$ of the plants exhibiting typical symptoms of rhizomania. This level of disease reduced root yield and quality and resulted in significant economic losses for both the grower and processor (C. M. Rush, unpublished data). Whether this observed level of disease is caused by a new strain of BNYVV or some other factor is unknown, but regardless of the cause, pressure on seed companies to develop regionally adapted cultivars with increased levels of resistance to rhizomania is swiftly mounting.

The large-scale planting of rhizomaniatolerant cultivars with a single source of resistance has placed tremendous selection pressure on BNYVV and put the U.S. sugar beet industry at risk. When placed under such selection pressure, it is not surprising that populations of BNYVV would evolve, resulting in partial or total breakdown of resistant cultivars $(18,53,59)$. When rhizomania is first detected in a field, yield loss is often minimal because inoculum densities are low and distribution is localized. Over the years, this has given some producers a false sense of security, and they have been hesitant to plant rhizomania-tolerant cultivars until they experienced a significant loss. Now some will be afraid to plant resistant cultivars because of the potential for future development of a new strain of BNYVV in their field, but also afraid not to plant resistant cultivars because of the potential for a total crop failure due to rhizomania. This concern is legitimate and highlights the need for development of new regionally adapted cultivars with multiple sources of resistance to BNYVV. In the mean time, producers can help delay development of resistant-breaking BNYVV in their fields through sanitation that minimizes introduction of viruliferous $P$. betae, cultural practices that optimize crop water use effi- ciency and reduce prolonged periods of soil saturation, and extending rotations to slow the selection and increase of resistance-breaking strains of BNYVV.

\section{Acknowledgments}

We thank the Beet Sugar Development Foundation, the California Beet Grower's Association, and the Minnesota-North Dakota Research and Education Board for partially funding portions of the research reported in this review. We also thank $\mathrm{Al}$ Cattanach, American Crystal Sugar Beet Cooperative, Mark Bredehoeft and Steve Roehl, Southern Minnesota Sugar Beet Cooperative, and Ron Tharp, Holly Sugar, for field and technical support.

\section{Literature Cited}

1. Adams, M. J. 1991. Transmission of plant viruses by fungi. Ann. Appl. Biol. 118:479-492.

2. Asher, M. J. C., Chwarszczynska, D. M., and Leaman, M. 2002. The evaluation of rhizomania tolerant sugar beet for the UK. Ann. Appl. Biol. 141:101-109.

3. Bangsund, D. A., and Leistritz, F. L. 2004 Economic contribution of the sugar beet industry in Minnesota, North Dakota, and Eastern Montana. Agribusiness and Economics Report No. 532. Department of Agribusiness and Applied Economics. Agriculture Experiment Station, North Dakota State University, Fargo.

4. Biancardi, E., Lewellen, R. T., DeBiaggi, M Erichsen, A. W., and Stevanato, P. 2002. The origin of rhizomania resistance in sugar beet Euphytica 127:383-397.

5. Braselton, J. P. 2001. Plasmodiophoromycota Pages 81-91 in: The Mycota: A Comprehensive Treatise on Fungi as Experimental Systems for Basic and Applied Research. VII Systematics and Evolution. Springer-Verlag, Berlin.

6. Breum, D. 2005. Another world record crop for California's Imperial Valley. Sugar Beet Grower Magazine 24:16-18.

7. Brewton R. G., Lee, L., and Rush, C. M. 1999 Genetic diversity in Beet soilborne mosaic vi rus revealed by SSCP analysis. Pages 1-4 in: Proc. Sympos. Int. Working Group Plant Viruses Fungal Vectors, 4th. J. L. Sherwood and C. M. Rush, eds. American Society of Sugar Beet Technologists, Denver, CO.

8. Büttner, G., Büchse, A., Holtschulte, B., and Märländer, B. 2004. Pathogenicity of different 


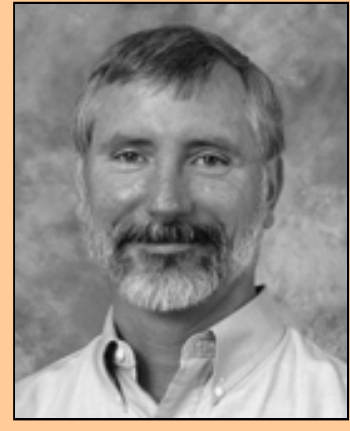

Charles M. Rush

Dr. Rush received a B.A. degree in literature from the University of Texas Permian Basin in 1974. He attended Texas A\&M and, under the direction of Dr. Stuart Lyda, received a Master of Agriculture degree in plant protection in 1976 and a $\mathrm{Ph} . \mathrm{D}$. in plant pathology in 1981. He worked as a postdoctorate with the Texas Agriculture Experiment Station in Temple from 1981 to 1983 and with USDA-ARS in Prosser, WA, from 1983 to 1986 . He was hired as an associate professor with TAES in Amarillo in 1986 and was promoted to professor in 1991. Dr. Rush currently leads a diverse research program that includes projects on rhizomania of sugar beet, Karnal bunt, sorghum ergot, Wheat streak mosaic virus, and remote sensing for detection and quantification of plant disease. His work on rhizomania has focused on disease management, and pathogen ecology and epidemiology.

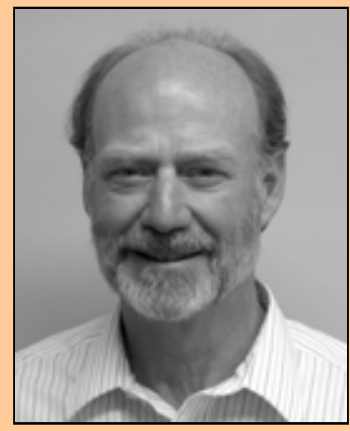

Robert Lewellen

Dr. Lewellen is a research geneticist with the USDA-ARS at the U.S. Agricultural Research Station, Crop Improvement and Protection Research Unit, Salinas, CA. He received his B.S. from Oregon State University and his Ph.D. from Montana State University. Since 1966, he has been at Salinas working on genetics and breeding of sugar beet with emphasis on population improvement, germ plasm enhancement, and host-plant resistance. Dr. Lewellen has developed germ plasm lines with new and improved combinations of resistances to virus yellows, erwinia soft rot, powdery mildew, lettuce infectious yellows, curly top, and rhizomania. Current emphasis is on resistance from wild species to the new strains of BNYVV and to sugar beet cyst nematode.

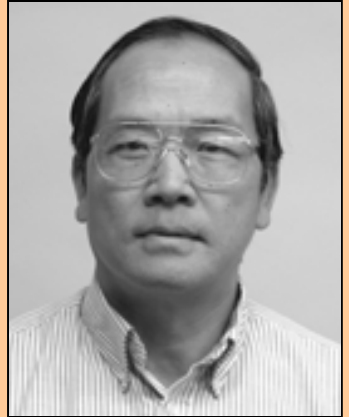

Hsing-Yeh Liu

Dr. Liu is a research plant pathologist with the USDA-ARS Crop Improvement and Protection Unit in Salinas, CA. He received his Ph.D. in plant pathology in 1981 from the University of California, Riverside. He joined the USDA-ARS in 1984. His current research interests are on virus diseases of sugar beet and vegetables, with special emphasis on biological, serological, and molecular characterization of virus, virus-vector relationships, epidemiology, and control strategies of vector-borne virus diseases.

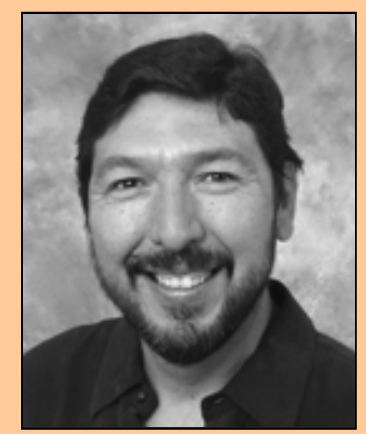

Rodolfo Acosta-Leal

Dr. Acosta-Leal earned his B.S. degree from the Universidad Autonoma de Nuevo Leon, Mexico. He worked as a research instructor in the Comision Nacional de Fruticultura where he studied the pathogenic variability of Papaya ringspot virus. After earning an M.S. degree from the Centro de Fitopatologia, Colegio de Postgraduados, Mexico, he worked as an agricultural researcher in INIFAP studying the etiology and epidemiology of whitefly-transmitted virus diseases. In 1999, he earned a Ph.D. from the University of Arizona where he studied the cellular and molecular aspects of plant resistance mechanisms and resistance-breaking mechanisms of plant viruses. Following graduation, he accepted a postdoctorate fellowship at the Noble Foundation analyzing the replicative fidelity of infectious RNAs. Currently, he is working as an assistant research scientist at the Texas Agricultural Experiment Station, Amarillo, exploring resistance-breaking isolates of BNYVV. forms of Beet necrotic yellow vein virus (BNYVV) on sugar beet - Is there evidence for the development of pathotypes? Pages 263270 in: Proc. 67th I.I.R.B. Congress, Brussels, Belgium.

9. Campbell, R. N. 1996. Fungal transmission of plant viruses. Annu. Rev. Phytopathol. 34:87108.

10. DeBiaggi, M. 1987. Methodes de selection un cas concret. Pages 157-161 in: Proc. 50th Winter Congress, I.I.R.B., Brussels, Belgium.

11. Doney, D. L., Whitney, E. D., Terry, J., Frese, L., and Fitzgerald, P. 1990. The distribution and dispersal of Beta vulgaris L. ssp. maritima germplasm in England, Wales, and Ireland. J. Sugar Beet Res. 27:29-37.

12. Duffus, J. E., Whitney, E. D., Larsen, R. C., Liu, H.-Y., and Lewellen, R. T. 1984. First report in Western hemisphere of rhizomania of sugar beet caused by beet necrotic yellow vein virus. Plant Dis. 68:251.

13. Fauquet, C., Desbois, D., Fargette, D., and Vidal, G. 1988. Classification of Furoviruses based upon the amino acid composition of their coat proteins. Devel. Appl. Biol. 2:19-36.

14. Francis, S. A., Redfearn, M., Chwarszczynska, D. M., Asher, M. J. C., and Lewellen, R. T. 1998. Use of molecular markers in breeding for disease resistance in sugar beet (Beta vulgaris L.). Asp. Appl. Biol. 52:279-285.

15. Gerik, J. S., and Duffus, J. E. 1988. Differences in vectoring ability and aggressiveness of isolates of Polymyxa betae. Phytopathology 78:1340-1343.

16. Gidner, S., Lennefors, B.-L., Nilsson, N.-O Bensefelt, J., Johansson, E. Gyllenspetz, U., and Kraft, T. 2005. QTL mapping of BNYVV resistance from the WB41 source of sugar beet. Genome 48:279-285.

17. Harju, V. A., Mumford, R. A., Blockley, A., Boonham, N., Clover, G. R. G., Weekes, R. and Henry, C. M. 2002. Occurrence in the United Kingdom of Beet necrotic yellow vein virus isolates which contain RNA 5. Plant Pathol. 51:811.

18. Harrison, B. D. 2002. Virus variation in relation to resistance-breaking in plants. Euphytica 124:181-192.

19. Harveson, R. M., and Rush, C. M. 1993. An environmentally controlled experiment to monitor the effect of aphanomyces root rot and rhizomania on sugar beet. Phytopathology 83:1220-1223.

20. Harveson, R. M., and Rush, C. M. 1994. Evaluation of fumigation and rhizomaniatolerant cultivars for control of a root disease complex of sugar beets. Plant Dis. 78:11971202.

21. Harveson, R. M., and Rush, C. M. 2002. The influence of irrigation frequency and cultivar blends on the severity of multiple root diseases in sugar beets. Plant Dis. 86:901-908.

22. Harveson, R. M., Rush, C. M., and Wheeler, T A. 1996. The spread of beet necrotic yellow vein virus from point source inoculations as influenced by irrigation and tillage. Phytopathology 86:1242-1247.

23. Heidel, G. B., Rush, C. M., Kendall, T. L. Lommel, S. A., and French, R. C. 1997. Characteristics of beet soilborne mosaic virus, Furo-like virus infecting sugar beet. Plant Dis. 81:1070-1076.

24. Heijbroek, W., Musters, P. M. S , and Schoone, H. L. 1999. Variation in pathogenicity and multiplication of Beet necrotic yellow vein virus (BNYVV) in relation to the resistance of sugar beet cultivars. Eur. J. Plant Pathol 105:397-405.

25. Jupin, I., Guilley, H., Richards, K. E., and Jonard, G. 1992. Two proteins encoded by Beet necrotic yellow vein virus RNA 3 influence symptom phenotype on leaves. EMBO J. 11:479-488.

26. Jupin, I., Tamada, T., and Richards, K. E. 
1991. Pathogenesis of Beet necrotic yellow vein virus. Virology 2:121-129.

27. Kaufmann, A., Koenig, R., and Lesemann, D.E. 1992. Tissue print-immunoblotting reveals an uneven distribution of Beet necrotic yellow vein and Beet soilborne viruses. Arch. Virol. 126:329-335

28. Koenig, R., Beier, C., Commandeur, U., Luth, U., Kaufmann, A., and Luddecke, P. 1996. Beet soilborne virus RNA 3 - A further example of the heterogeneity of the gene content of Furovirus genomes and of triple gene blockcarrying RNAs. Virology 216:202-207.

29. Koenig, R., Burgermeister, W., Weich, H., Sebald, W., and Kothe, C. 1986. Uniform RNA patterns of Beet necrotic yellow vein virus in sugar beet roots, but not in leaves from several plant species. J. Gen. Virol. 67:2043-2046.

30. Koenig, R., Haeberle, A. M., and Commandeur, U. 1997. Detection and characterization of a distinct type of Beet necrotic yellow vein virus RNA 5 in a sugar beet growing area in Europe. Arch. Virol. 142:1499-1504.

31. Koenig, R., and Lennefors, B.-L. 2000. Molecular analyses of European A, B and P type sources of Beet necrotic yellow vein virus and detection of the rare $\mathrm{P}$ type in Kazakhstan. Arch. Virol. 145:1561-1570.

32. Koenig, R., Luddecke, P., and Haeberle, A. M. 1995. Detection of Beet necrotic yellow vein virus strains, variants and mixed infections by examining single-strand conformation polymorphisms of immunocapture RT-PCR products. J. Gen. Virol. 76:2051-2055.

33. Kruse, M., Koenig, R., Hoffmann, A., Kaufmann, A., Commandeur, U., Solovyev, A. G., Savenkov, I., and Burgermeister, W. 1994. Restriction fragment length polymorphism analysis of reverse transcription-PCR products reveals the existence of two major strain groups of Beet necrotic yellow vein virus. J. Gen. Virol. 75:1835-1842.

34. Lauber, E., Bleykasten-Grosshans, C., Erhardt, M., Bouzoubaa, S., and Jonard, G. 1998. Cell to cell movement of Beet necrotic yellow vein virus: I. Heterologous complementation experiments provide evidence for specific interactions among the triple gene block proteins. Mol. Plant-Microbe Interact. 11:618-625.

35. Lee, L., Telford, E. B., Batten, J. S., Scholthof, G. K.-B., and Rush, C. M. 2001. Complete nucleotide sequence and genome organization of Beet soilborne mosaic virus, a proposed member of the genus Benyvirus. Arch. Virol. 140:2443-2453.

36. Lewellen, R. T. 1988. Selection for resistance to rhizomania in sugar beet. Abstr. Int. Congr. Plant Pathol., 5th, Kyoto, Japan, 455.

37. Lewellen, R. T. 1995. Performance of nearisolines of sugarbeet with resistance to rhizomania from different sources. Pages 83-91 in: Proc. 58th I.I.R.B. Congress, Beaune, France.

38. Lewellen, R. T. 1995. Registration of sugar beet germplasm lines with multiple disease resistance: C39, C39R, C39R-6, C47, C47R, C93, and C94. Crop Sci. 35:596-597.

39. Lewellen, R. T. 1997. Registration of 11 sugar beet germplasm C79 lines with resistance to rhizomania. Crop Sci. 37:1026.

40. Lewellen, R. T. 2000. Registration of rhizomania tolerant sugar beet $\times$ Beta vulgaris subsp. maritima germplasms C26, C27, and C51. Crop Sci. 40:1513-1515.

41. Lewellen, R. T. 2004. Registration of sugar beet germplasm lines C67/2, C69/2, C78/3, and $\mathrm{C} 80 / 2$ with resistance to virus yellows and rhizomania. Crop Sci. 44:358-359.

42. Lewellen, R. T., and Biancardi, E. 1990. Breeding and performance of rhizomania tol- erant sugar beet. Pages 79-84 in: Proc. 53rd Winter Congress, I.I.R.B., Brussels, Belgium.

43. Lewellen, R. T., Liu, H.-Y., Wintermantel, W. M., and Sears, J. L. 2003. Inheritance of Beet necrotic yellow vein virus (BNYVV) systemic infection in crosses between sugar beet and Beta macrocarpa. Pages 149-160 in: Proc. 1st Joint IIRB-ASSBT Congress, San Antonio, TX.

44. Lewellen, R. T., Skoyen, I. O., and Erichsen, A. W. 1987. Breeding sugarbeet for resistance to rhizomania: Evaluation of host-plant reactions and selection for and inheritance of resistance. Pages 139-156 in: Proc. 50th Winter Congress, I.I.R.B., Brussels, Belgium.

45. Lewellen, R. T., and Whitney, E. D. 1993. Registration of germplasm lines developed from composite crosses of sugarbeet $\times$ Beta maritima. Crop Sci. 33:882-883.

46. Lewellen, R. T., Whitney, E. D., and Skoyen, I. O. 1985. Registration of C37 sugarbeet parental line. Crop Sci. 25:375

47. Liu, H.-Y., Sears, J. L., and Lewellen, R. T. 2005. Occurrence of resistance-breaking Beet necrotic yellow vein virus of sugar beet. Plant Dis. 89:464-468.

48. Mahmood, T., and Rush, C. M. 1999. Evidence of cross protection between beet soilborne mosaic virus and beet necrotic yellow vein virus in sugar beet. Plant Dis. 83:521-526.

49. Mayo, M. A. 1999. Developments in plant virus taxonomy since the publication of the 6th ICTV Report. Arch. Virol. 144:1659-1666.

50. McGrath, J. M., and Lewellen, R. T. 2004. Registration of EL0204 sugar beet germplasm with smooth-root and resistance to rhizomania. Crop Sci. 44:1032-1033.

51. Meunier, A., Schmit, J.-F., and Bragard, C. 2003. Sequences analysis of Belgian isolates of $B N Y V V$ and development of a simultaneous detection of sugar beet virus by RT-PCR. Pages 9-12 in: Proc. Sympos. Int. Working Group Plant Viruses Fungal Vectors, 5th. C. M. Rush and U. Merz, eds. American Society of Sugar Beet Technologist, Denver, CO.

52. Miyanishi, M., Kusume, T., Saito, M., and Tamada, T. 1999. Evidence for three groups of sequence variants of Beet necrotic yellow vein virus RNA5. Arch. Virol. 144:879-892.

53. Pelham, J., Fletcher, J. T., and Hawkins, J. H. 1970. The establishment of a new strain of Tobacco mosaic virus resulting from the use of resistant varieties of tomato. Ann. Appl. Biol. 65:293-297.

54. Pelsy, F., and Merdinoglu, D. 1996. Identification and mapping of random amplified polymorphic DNA markers linked to a rhizomania resistance gene in sugar beet (Beta vulgaris L.) by bulked segregate analysis. Plant Breed. 115:371-377.

55. Prillwitz, H., and Schlosser, E. 1993. Interactions between Beet soilborne virus BSBV-2) and Beet necrotic yellow vein virus (BNYVV). Pages 71-74 in: Proc. Sympos. Int. Working Group Plant Viruses Fungal Vectors, 2nd. C. Hiruki, ed. American Society of Sugar Beet Technologists, Denver, CO.

56. Putz, C. 1977. Composition and structure of Beet necrotic yellow vein virus. J. Gen. Virol. 35:397-401.

57. Richards, K., and Tamada, T. 1992. Mapping functions on the multipartite genome of Beet necrotic yellow vein virus. Annu. Rev. Phytopathol. 30:291-313.

58. Richard-Molard, M. 2002. Rhizomania: Interactions varieties $\mathrm{x}$ lieux et consequences. Pages 239-245 in: Proc. 65th I.I.R.B. Congress, Brussels, Belgium.

59. Roossinck, M. J. 1997. Mechanisms of plant virus evolution. Annu. Rev. Phytopathol.
35:191-209.

60. Rush, C. M. 2003. Ecology and epidemiology of Benyviruses and plasmodiophorid vectors. Annu. Rev. Phytopathol. 41:567-592.

61. Rush, C. M., and Heidel, G. B. 1995. Furovirus diseases of sugar beets in the United States. Plant Dis. 79:868-875.

62. Rush, C. M., and Merz, U., eds. 2003. Proc. Sympos. Int. Working Group Plant Viruses Fungal Vectors, 5th. American Society of Sugar Beet Technologists, Denver, CO.

63. Scholten, O. E., DeBock, T. S. M., KleinLankhorst, R. M., and Lange, W. 1999. Inheritance of resistance to beet necrotic yellow vein virus in Beta vulgaris conferred by a second gene for resistance. Theor. Appl. Genet. 99:740-746.

64. Scholten, O. E., Jansen, R. C., Keiser, L. C. P., DeBock, T. S. M., and Lange, W. 1996. Major genes for resistance to beet necrotic yellow vein virus (BNYVV) in Beta vulgaris Euphytica 91:331-339.

65. Scholten, O. E., Klein-Lankhorst, R. M., Esselink, D. G., DeBock, T. S. M., and Lange, W. 1997. Identification and mapping of random amplified polymorphic DNA (RAPD) markers linked to resistance against beet necrotic yellow vein virus (BNYVV) in Beta accessions. Theor. Appl. Genet. 94:123-130.

66. Scholten, O. E., and Lange, W. 2000. Breeding for resistance to rhizomania in sugar beet: A review. Euphytica 112:219-231.

67. Shirako, Y., Suzuki, N., and French, R. C. 2000. Similarity and divergence among viruses in the genus Furovirus. Virology 270:201-207.

68. Tamada, T. 1999. Benyviruses. Pages 154-160 in: Encyclopedia of Virology. R. G. Webster and A. Granoff, eds. Academic Press, London.

69. Tamada, T., Kusume, T., Uchino, H., Kiguchi, T., and Saito, M. 1996. Evidence that Beet necrotic yellow vein virus RNA 5 is involved in symptom development of sugar beet roots. Pages 49-52 in: Proc. Sympos. Int. Working Group Plant Viruses Fungal Vectors, 3rd. J. L. Sherwood and C. M. Rush, eds. American Society of Sugar Beet Technologists. Denver, CO.

70. Tamada, T., Miyanishi, M., Kondo, H., Chiba, S., and Han, C. G. 2003. Pathogenicity and molecular variability of Beet necrotic yellow vein virus isolates from Europe, Japan, China, and the United States. Pages 13-16 in: Proc. Sympos. Int. Working Group Plant Viruses Fungal Vectors, 5th. C. M. Rush and U. Merz, eds. American Society of Sugar Beet Technologists, Denver, CO.

71. Torrance, L., and Mayo, M. A. 1997. Proposed re-classification of Furoviruses. Arch. Virol. 142:435-439.

72. Villanueva, E., and Rush, C. M. 2003. Genetic variability of isolates of Beet soilborne mosaic virus. J. Sugar Beet Res. 40:141.

73. Webster, R. G., and Granoff, A., eds. 1999 Encyclopedia of Virology. Academic Press, London.

74. Whitney, E. D. 1989. Identification, distribution, and testing for resistance to rhizomania in Beta maritima. Plant Dis. 73:287-290.

75. Wisler, G. C., Lewellen, R. T., Sears, J. L., Liu, H.-Y., and Duffus, J. E. 1999. Specificity of TAS-ELISA for beet necrotic yellow vein virus and its application for determining rhizomania resistance in field-grown sugar beets. Plant Dis. 83:864-870.

76. Wisler, G. C., Lewellen, R. T., Sears, J. L., Wasson, J. W., Liu, H.-Y., and Wintermantel, W. M. 2003. Interaction between Beet necrotic yellow vein virus and Beet soilborne mosaic virus in sugar beet. Plant Dis. 87:1170-1175. 